\title{
Success of manufacturing industries - Role of Six Sigma
}

\author{
N. Venkatesh ${ }^{1 *}$ and C. Sumangala ${ }^{2}$ \\ ${ }^{1}$ Department of Mechanical Engineering, Canara College of Engineering, Benjanapadavu, Bantwal \\ 574 219, Karnataka, India \\ ${ }^{2}$ Department of MBA, University of Mysore, Mysore 570005, Karnataka, India
}

\begin{abstract}
Six Sigma is a phenomenal quality management concepts which has helped many organizations to overcome quality crisis in the recent past. Six Sigma is observed as a very promising quality management tool for any organization to make its presence felt in the corporate world as it emphasizes on obtaining a fruitful solution to improve accuracy, reduce defect thereby reduce the cost and improve profits. The main objective of this investigation is to unearth the extent to which the companies have been benefitted due to Six Sigma implementation. This article presents the results based on the analysis of collective opinion of employees of various Indian manufacturing industries that have implemented Six Sigma. This research also examines interrelationship among various parameters defined in the research. The research revealed that industries are benefitted irrespective of their nature in terms of their growth, financial benefits, productivity and satisfaction of the customer. However, peoples' equity that deals with the benefits that employees obtain after Six Sigma implementation is not certain. The research also revealed the existence of strong interrelationship among various parameters used to measure the success of Six Sigma.
\end{abstract}

Keywords: Six Sigma; Qualitative analysis; manufacturing industry.

\section{Introduction}

The Six Sigma philosophy aims to maintain a process within control limits in order to record no defects (Arendt, 2008). Motorola developed Six Sigma in the 1980s with focus on application in manufacturing entities. In the last two decades, it is observed that global companies have maximised business benefits and gained competitive advantage by implementing Six Sigma (Yang and Hsieh, 2009, Su and Chou, 2008,). Six Sigma has been defined as a systematic and organised method of improving process and development of new products and services that rely on statistical and scientific methods to reduce customer- defined defect rates to a very high level (Linderman et al., 2003). A Six Sigma process approaches 'zero defects', which means only 3.4 Defects Per Million Opportunities (DPMO) might occur. The difference between Six Sigma and other quality programmes is its 'top-down' drive and its rigorous methodology combined with

*Corresponding author: venksati@gmail.com 
detailed analysis, factual decisions, and a concrete control plan to ensure that ongoing quality control of a process is achieved (Markarian J, 2004). Besides, Six Sigma methodology enables practitioners to accurately remove hindering issues and demonstrate the improvements using statistical tools such as Pareto Chart and control charts (Kapur and Feng, 2005, Feng and Manuel, 2008).

Researchers have done lot of work regarding the theory and implementation of Six Sigma at various industries in many developed countries. It is therefore required similar kind of studies in other parts of the world as well. Developing nations in particular need to understand factors affecting Six Sigma implementation. Moreover, the report on Six Sigma implementation and its potential benefits in a developing country like India look scanty (Padhy et al., 2011). In the days to come India will face huge competition from china in the manufacturing sector including garments (Chethan Kumar et al., 2010). Many medium scale garment industries in India are not aware of the lean Six Sigma concepts and this implementation will trigger a positive wave across the garment industries and become more competitive (Chethan Kumar et al., 2010). Six Sigma is not being explored by the developing countries to its full potential and India is not an exception in this (Desai and Patel, 2009).

After globalization and liberalization policies of the Indian government during 1990's quality along with productivity has emerged as one of the major areas of concern. It was inevitable for the Indian companies to improve quality or perish in face of stiff competition from global companies. Many Indian industries have reaped success through this breakthrough strategy of business improvement to achieve overall benefits by joining hands with Japanese and western companies via joint ventures. Still it is felt that Six Sigma has not penetrated Indian industries to the level it should have been. Hence, there is an enormous scope for Indian industries, to utilize Six Sigma strategy strengthen their business to have a winning edge in the global market.

\section{Literature review}

Changes of global industrial scenario compelled the Indian Government to introduce Liberalisation, Privatisation, and Globalisation (LPG), during early 1990's. Due to this several reforms in the form of encouragement for Foreign Direct Investment (FDI), removal of 'quota raj', and supporting IT sector for improved exports were introduced. These changes inspired several multinational automobile and electronics companies to open their units in India. As a result of which Indian automobile industries also changed their stance towards quality of product and processes. Six Sigma was introduced by many Indian manufacturing industries thenceforth (Desai and Patel, 2009).

Kaushik and Khanduja (2009) applied and analysed the application of Six Sigma DMAIC methodology in one of the thermal power plants. Their effort has paid off very well as claimed by them. They targeted the reduction of usage of de-mineralised water in a thermal plant as $0.1 \%$ of the extra use, costs the plant an extra 85 lacs. After the implementation of Six Sigma they are able to control the usage of de-mineralised water due to which the company has saved nearly 300 lacs per annum in the form of reduced energy consumption.

Kaushik (2011) in his paper "Relevance of Six Sigma line of attack in SME's: a case study of die casting manufacturing unit", has conducted an analysis of the effect of Six Sigma implementation. The DMAIC methodology applied in the organization to reduce the defect in die casting industry manufacturing Engine Mounting Brackets, resulted in an improvement of sigma level from 1.64 to 5.14. This improvement of sigma level transformed into an annual savings of Rs. 2.6 lacs.

Min Zhang et al. (2014) in their case study at one of the steel plants in China have 
observed that the implementation of Six Sigma in 470 projects resulted in savings of \$100millions.

Srinivasan et al. (2016) have proved in their study how powerful the DMAIC approach is in improving Six sigma level from 3.31 to 3.67 .

Thomas, et al. (2016) in their case study of application of Lean Six Sigma (LSS) at an aerospace industry have observed that the company is able to reduce the non value adding times, improved on-time delivery to customer and have estimated a savings of $£ 2$ millions due to LSS.

Venkatesh and Sumangala et al. (2014) in their qualitative study of application of Six Sigma in an automobile industry highlighted the importance of opinion of six sigma experts in the success of Six Sigma. In their paper they have concluded that employees of different automobile industries have come with the opinion that contribution of Six Sigma is significant in improving the productivity, customer satisfaction, and finances. However, the contribution of Six Sigma is not so significant in improving employees' conditions in automobile industries.

The present study is continuation of qualitative study of manufacturing industries wherein electronics and pharmaceutical industries are also included in the study.

The literatures referred above clearly highlighted Six Sigma as one of the most prominent tools of quality management to achieve required quality. Indian manufacturing industries are putting their efforts to implement Six Sigma and compete at the global level. However, very few studies have tried to explore opinion of employees who have practiced and implemented Six Sigma in manufacturing industries. Under these circumstances there is a strong need of survey of Indian industries, which have implemented Six Sigma. Hence, this research intends to investigate the role of Six Sigma in the success of industries. This in turn helps the non Six Sigma companies to implement the practices that are most suitable for them.

\section{Objectives of the study}

This paper makes an attempt to examine few companies that have implemented Six Sigma. Industries selected included ten Mechanical based industries, eight Electronics industries and two Pharmaceutical industries.

The objectives of the study are:

1. Investigate the extent to which the companies have been benefitted due to Six Sigma implementation under the following five parameters:

a) Growth of the company

b) Financial benefits

c) Peoples' equity

d) Productivity

e) Customer satisfaction

2. Examine the interrelationship among various benefits defined.

\section{Research methodology}

To start the survey the following variables were identified as benefits that companies can enjoy after implementing Six Sigma.

1. Growth of the company - The growth of the company is measured using nine parameters viz. improved revenue, improved organization structure, expansions, increased recruitments, higher exports, higher share value, better brand image, new product development and competitive edge after introducing Six Sigma. 
2. Financial benefits - The financial benefits are measured using eight parameters viz. improved sales, better revenue, reduced Price Of Non Conformance, lesser cost of poor quality, increased profit, rate of return, safe position in the market and whether the benefits are from Six Sigma alone.

3. Productivity - This parameter is measured by considering following eighteen factors: reduced inventory, cost of set up, reduced cost of operations, Standard production methods, appropriate selection of the project, continuous monitoring after every project, removal of non-productive steps, continuous Identification and elimination of defects in the process, reduction of time to complete the project, continuous reduction of variation of the process, responding quickly to changes in demand of the market, lesser defect rate, lesser scrap rate, lesser rejection rate, reduced production lead time, better process capability, considering both short as well as long term goals and utilization of the resources optimally after implementation of Six Sigma.

4. Peoples' equity - This parameter defined by such factors, which are expected to contribute to welfare of employees. Twenty seven factors were identified. They are commitment from top management, resources provided by senior management, proper leadership style, fact based decision making instead of hierarchy, increased employee involvement in making decisions, learning process adopted by employees', knowledge of Six Sigma techniques and tools, training based on needs, Incentive programme, management values high for human beings, improved interpersonal relationships, improved employee participation, recognition and rewards for Employees, Improved morale, better communication skills, improved work culture, increased pride in work, change in work culture, involvement of employees in getting customers' feedback, helping knowledge sharing between employees, Overall commitment from employees, better employee retention, Employees enjoy change, suppliers show improved commitment, enjoy the Six Sigma implementation, and Employees' willingness to work with Six Sigma projects.

5. Customer satisfaction - Customer satisfaction is measured by sixteen different factors viz. Defining needs of customers, better satisfaction of customer, making products available of as per the needs of customers, better customer relationships, better commitment for customers' needs, Completely shifting focus towards customers, customers feedback, developing products based on needs of customers, sharing production plans with customers, making customers a part of the company, setting up of customer redressal mechanism, satisfy customers through continued service, risks and rewards are shared with customers, Reduction in customers' complaints, better customer relationship and achieve Competitive pricing policy through Win - Win situation with customers.

\subsection{Hypotheses of the study}

Following hypotheses were stated based on the earlier mentioned variables selected for the study.

During discussion with statisticians it was suggested by them to use only null hypotheses as against the normal procedure of stating both null and alternate hypotheses together. The positive form of a null hypothesis is deemed as alternate hypothesis. To make decisions, while testing hypotheses, if the obtained significance value is less than 0.05 from the SPSS software, the null hypotheses are rejected which means the alternate hypotheses are accepted. The hypotheses of the study are:

HA0: Existing practices of Six Sigma do not improve growth of the company.

HB0: Financial status of the company is independent of existing practices of Six

Sigma. HC0: Improvement of Productivity is independent of existing 
practices of Six Sigma.

HD0: Existing practices of Six Sigma do not improve peoples' equity.

HE0: Existing practices of Six Sigma do not improve customer satisfaction.

HF0: There is no relationship among the benefits of Six Sigma.

\subsection{Sample population}

Sample Population included 522 employees with direct involvement in implementation of Six Sigma from 20 different manufacturing industries which have implemented Six Sigma in Karnataka, India. While selecting the industry for the survey, it was observed that many industries were in very primitive state with respect to six sigma implementation. Hence, employees were reluctant to share the opinion. Thus, it was decided to select such industries which have implemented six sigma at least for five years and few projects have been completed. Based on this fact, industries selected included ten Mechanical based industries, eight Electronics industries and two Pharmaceutical industries. Again, while selecting the respondents, only such of those employees who are involved in six sigma projects are considered. Because, the data could not be very relevant if it is collected from those whose knowledge on six sigma is limited. The respondents selected were in the cadre of both workers and managers with sufficient training in Six Sigma implementation. Six Sigma training was given to obtain certificates as master black belts, black belts and green belts as well. Out of 522 respondents, 380 were considered as worker and 142 as supervisors or managers.

\section{Research design}

To begin the study, the collection of data was done using a questionnaire. The questionnaire was prepared by considering five parameters which are believed to be reasons for the success of industries. They are Growth of the company, Financial benefits, Productivity, Peoples' equity and Customer satisfaction.Questionnaire was thoroughly revised and pilot-tested with the help of experts and practitioners of Six Sigma both as academia and industry. The process helped to evaluate and validate the questionnaire. Finally the questionnaire included 09 parameters that define growth of the company, 08 parameters that define the financial benefits, 18 parameters that define productivity, 27 parameters that define peoples' equity and 16 parameters that define customer satisfaction (total 78). Proper care was taken to frame questions around above defined parameters in such a language which even a layman can understand. Even vernacular language of employees was used to explain the purpose of the survey and the content of the questionnaire. A Five point Likert scale with a lowest degree of agreement (strongly disagree $=1$ ) to the highest degree of agreement (strongly agree $=5$ ) was selected to collect respondents' opinion in an objective manner.

A thorough analysis of the results of the study was done to observe the effect of Six Sigma towards suggested variables. SPSS V16, one of the most commonly used Statistical tool was used to analyze the outcome of the study.

\section{Results and interpretations}

As a first step towards the analysis, after collecting the data, Cronbach's alpha test was used to test the reliability of the questionnaire. The following table 1 gives details of the reliability analysis. 
Table 1. Reliability Statistics

\begin{tabular}{|l|c|c|}
\hline \multicolumn{1}{|c|}{ Variable } & Number of items & Cronbach's alpha \\
\hline Growth of the company & 9 & 0.891 \\
\hline Financial benefits & 8 & 0.867 \\
\hline Productivity & 18 & 0.782 \\
\hline Peoples' equity & 27 & 0.892 \\
\hline Customer satisfaction & 16 & 0.894 \\
\hline Overall & $\mathbf{7 8}$ & $\mathbf{0 . 9 6 1}$ \\
\hline
\end{tabular}

Since all the individual parameters and also the overall alpha value scored the Cronbach's alpha value more than 0.7 (Nunnaly, 1978), the testing instrument is proved to be reliable. Next, to select the type of the test, we conducted the normality test. Table 2 gives the result of Kolmogorov-Smirnov test for normality.

Table 2. Result of Kolmogorov-Smirnov Test of normality

\begin{tabular}{|c|r|r|r|r|r|}
\hline \multirow{2}{*}{$\begin{array}{c}\text { Normal } \\
\text { Parameters }\end{array}$} & \multicolumn{5}{|c|}{ Benefits of Six Sigma } \\
\cline { 2 - 6 } & $\begin{array}{c}\text { Customer } \\
\text { satisfaction }\end{array}$ & $\begin{array}{c}\text { Financial } \\
\text { benefits }\end{array}$ & $\begin{array}{c}\text { Growth of the } \\
\text { company }\end{array}$ & $\begin{array}{c}\text { Peoples' } \\
\text { equity }\end{array}$ & Productivity \\
\hline Mean & 61.0820 & 30.7787 & 33.4262 & 96.6557 & 68.1148 \\
\hline Std. Deviation & 7.59468 & 2.05105 & 3.20619 & 11.89539 & 6.32481 \\
\hline P value & 0.142 & 0.005 & 0.215 & 0.047 & 0.158 \\
\hline
\end{tabular}

It was revealed from $\mathrm{K}-\mathrm{S}$ test that the distribution follows a pattern of normal curve with significant value ( $\mathrm{P}$ value) of more than 0.05 in all the cases except Financial benefits. This case has been discussed with the experts who have suggested assuming normal distribution. Hence, we will select $t$ - test for testing the hypotheses.

The following table 3 gives the frequency of responses in percentage for the scale parameters 
Table 3. Frequency of responses

\begin{tabular}{|l|c|c|c|c|c|}
\hline \multirow{2}{*}{$\begin{array}{l}\text { Scale } \\
\text { parameters }\end{array}$} & \multicolumn{5}{|c|}{ Percentage of responses } \\
\cline { 2 - 6 } & $\begin{array}{c}\text { Growth of the } \\
\text { company }\end{array}$ & $\begin{array}{c}\text { Financial } \\
\text { benefits }\end{array}$ & Productivity & $\begin{array}{c}\text { Peoples' } \\
\text { equity }\end{array}$ & $\begin{array}{c}\text { Customer } \\
\text { satisfaction }\end{array}$ \\
\hline $\begin{array}{l}\text { Strongly } \\
\text { disagree }\end{array}$ & 0.18 & 0.10 & 1.09 & 12.58 & 1.38 \\
\hline Disagree & 5.46 & 7.58 & 6.33 & 18.81 & 6.15 \\
\hline Can't say & 24.77 & 13.63 & 17.76 & 29.61 & 17.16 \\
\hline Agree & 61.93 & 69.67 & 62.70 & 33.65 & 59.94 \\
\hline $\begin{array}{l}\text { Strongly } \\
\text { agree }\end{array}$ & 7.65 & 9.02 & 12.11 & 5.35 & 15.37 \\
\hline
\end{tabular}

The frequency distribution Exhibit displays that as per the opinion of respondents all the five variables have been accepted as to be benefitted after the implementation of Six Sigma as more percentage of opinion is towards agree and strongly agree. This can be substantiated with the help of one sample t-test at a significance value of 0.05 for $521 \mathrm{df}$ $(\mathrm{N}-1)$.

\subsection{Testing of hypotheses}

\section{HA0. Existing practices of Six Sigma do not improve growth of the company.}

To test the hypothesis it is required to calculate the overall mean and standard deviation for the variable. The following table 4 gives the observed value of the mean for the above variable. The observed mean value for each variable is the total sum of all the individual mean values in each variable. For example, in growth of company, as explained earlier, there are nine factors. Hence, the mean value of growth of company is the sum of all these individual factors. The standard deviation is calculated for $N=522$. Same procedure is followed to calculate mean and standard deviation for remaining variables. Since manual calculation of mean and standard deviation for $\mathrm{N}=522$ is tedious, we have used SPSS V16 software, which will calculate as per the data input. Now this observed mean is compared against the test value as used by the company. A common practice among companies, where the research is done was observed to follow a of practice of accepting the results of a survey when the mean value of each question is more than or equal to 3.6. on a Likert scale of 1 to 5 . In this research each of the defined variables has more than one factor, used to measure it. Hence, the overall test value is calculated as (individual test value $\times$ number of factors used to measure the variable). For example, in case of growth of company, since there are nine factors, which measure it, the overall test value is $3.6 \times 9=32.4$. The same procedure is followed for all the variables.

With this we can observe that the calculated mean value is greater than test value. It gives the impression that implementation of Six Sigma has helped the company to grow. This can be substantiated with the help of one sample t-test conducted at a significance level of 0.05 at 521 degrees of freedom $(\mathrm{N}-1)$. The following table 4 gives the result of one 
sample t-test.

Table 4. Mean observed and expected values on growth of the company and results of one sample ttest

\begin{tabular}{|c|c|c|c|c|c|c|}
\hline & $\mathrm{N}$ & \begin{tabular}{l}
\multicolumn{2}{c|}{ Observed } \\
value \\
Mean
\end{tabular} & $\begin{array}{l}\text { Std. } \\
\text { Deviation }\end{array}$ & $\begin{array}{l}\text { Expected value } \\
\text { of Mean }\end{array}$ & t-value & $\mathrm{p}$-value \\
\hline $\begin{array}{l}\text { Growth of } \\
\text { the } \\
\text { company }\end{array}$ & 522 & 33.42 & 3.206 & 32.4 & 3.535 & $\begin{array}{l}0.001 \\
\text { (highly } \\
\text { significant) }\end{array}$ \\
\hline
\end{tabular}

The one sample t-test result shows that the calculated mean value is 33.42 as compared with the test value of 32.4 . Since, the significance value $p(0.001)<0.05$, the difference between observed and expected mean values on growth of the company is highly significant, $\mathrm{t}(521)=3.535, \mathrm{p}<0.05$. Since, the test statistics revealed significant difference between observed and expected mean values, one can say that there is a significant contribution to the growth of the company due to existing practices of Six Sigma hence, null hypothesis HAO is rejected.

\section{HB0: Financial status of the company is independent of existing practices of Six}

\section{Sigma.}

To test this hypothesis as a first step, it is required to calculate the overall mean and standard deviation for the variable. The following table 5 gives the value of the mean for the above variable. As explained earlier, since there are eight factors that measure the variable financial benefits, the overall test value is $3.6 * 8=28.8$. With this we can observe that the calculated mean value is more than test value. It seems that implementation of Six Sigma has helped the company to gain in terms of finance. This can be substantiated with the help of one sample t-test conducted at a significance level of 0.05 at 521 degrees of freedom $(\mathrm{N}-1)$. The following table 5 gives the result of one sample t-test

Table 5. Mean observed and expected values on financial benefits and results of one sample t-test

\begin{tabular}{|l|r|r|c|c|c|c|}
\hline & $\mathrm{N}$ & $\begin{array}{r}\text { Observ } \\
\text { ed value } \\
\text { of Mean }\end{array}$ & Std. Deviation & $\begin{array}{c}\text { Expected } \\
\text { value of Mean }\end{array}$ & $\begin{array}{l}\mathrm{t}- \\
\text { value }\end{array}$ & \multicolumn{1}{c|}{$\begin{array}{l}\mathrm{p}- \\
\text { value }\end{array}$} \\
\hline $\begin{array}{l}\text { Financial } \\
\text { benefits }\end{array}$ & 522 & 30.77 & 2.04 & 28.8 & 10.656 & $\begin{array}{l}0.000 \\
\text { (highly } \\
\text { significant) }\end{array}$ \\
\hline
\end{tabular}

The positive value of $t$ signifies that obtained mean is greater than the test value. Since the significance value $\mathrm{p}(0.000)<\mathrm{p}(0.05)$, this indicates that the contribution of Six Sigma towards the financial benefits is highly significant, $\mathrm{t}(521)=10.656, \mathrm{p}<0.05$. Hence, we can say that the implementation of Six Sigma has contributed significantly to the financial benefits of the organizations as per the opinions of the respondents. Thus null hypothesis $\mathrm{HBO}$ is rejected.

HC0: Improvement of Productivity is independent of existing practices of Six Sigma. 
To test this hypothesis as a first step, it is required to calculate the overall mean and standard deviation for the variable. The following table 6 gives the value of the mean for the above variable. As a matter of policy by the companies, since there are eighteen factors that define the variable productivity, the overall test value is $3.6 * 18=64.8$.

With this we can observe that the calculated mean value is more than test value. It looks as if the Six Sigma implementation has helped the company to improve productivity. This can be substantiated with the help of one sample t-test conducted at a significance level of 0.05 at 521 degrees of freedom $(\mathrm{N}-1)$. The following table 6 gives the result of one sample t-test.

Table 6. Mean observed and expected values on productivity and results of one sample ttest

\begin{tabular}{|r|r|r|r|r|r|r|}
\hline & $\mathrm{N}$ & $\begin{array}{c}\text { Observe } \\
\text { d value of } \\
\text { Mean }\end{array}$ & $\begin{array}{l}\text { Std. } \\
\text { Deviation }\end{array}$ & $\begin{array}{c}\text { Expected } \\
\text { value of } \\
\text { Mean }\end{array}$ & $\begin{array}{l}\mathrm{t}- \\
\text { value }\end{array}$ & $\begin{array}{c}\mathrm{p}- \\
\text { value }\end{array}$ \\
\hline Productivity & 522 & 68.1148 & 6.32481 & 64.8 & 5.789 & $\begin{array}{c}0.000 \\
\text { (highly } \\
\text { significant }\end{array}$ \\
\hline
\end{tabular}

The positive value of $t$ signifies that obtained mean is greater than the test value. Since the significance value $\mathrm{p}(0.000)<\mathrm{p}(0.05)$, this indicates that the contribution of Six Sigma towards improvement of productivity is significant, $\mathrm{t}(521)=5.789, \mathrm{p}<0.05$. Hence, we can say that the Six Sigma implementation has contributed significantly to the improvement of the productivity as per the opinions of the respondents. This indicates a significant relationship to improvement of productivity and the existing practices of Six Sigma. Thus hypothesis HCO is rejected.

\section{HD0: Existing practices of Six Sigma do not improve peoples' equity}

To test this hypothesis as a first step, it is required to calculate the overall mean and standard deviation for the variable. The following table 7 gives the value of the mean for the above variable. As a matter of policy by the companies, since there are twenty seven factors that define the variable peoples' equity, the overall test value is $3.6 * 27=97.2$.

With this we can observe that the calculated mean value is slightly less than test value. It appears that implementation of Six Sigma has not helped the company to improve peoples' equity significantly. This can be substantiated with the help of one sample t-test conducted at a significance level of 0.05 at 521 degrees of freedom (N-1).

Table 7. Mean observed and expected values on peoples' equity and results of one sample t-test

\begin{tabular}{|l|r|l|l|l|l|l|}
\hline & N & $\begin{array}{l}\text { Observed } \\
\text { value of } \\
\text { Mean }\end{array}$ & $\begin{array}{l}\text { Std. } \\
\text { Deviation }\end{array}$ & $\begin{array}{l}\text { Expected } \\
\text { value of } \\
\text { Mean }\end{array}$ & tvalue & p-value \\
\hline $\begin{array}{l}\text { Peoples' } \\
\text { equity }\end{array}$ & 522 & 96.65 & 11.89539 & 97.2 & 1.352 & $\begin{array}{l}0.179 \\
\text { (non } \\
\text { significant) }\end{array}$ \\
\hline
\end{tabular}

The one sample t-test results show that the calculated mean value is 96.65 as against the test value of 97.2. Since the significance value $p(0.179)>0.05$, the difference 
between observed and expected mean values on people' equity is not significant, $\mathrm{t}(521)=$ $1.352, \mathrm{p}>0.05$. Hence, the hypothesis fails to get rejected, since the test statistics revealed lower mean value than expected mean value as well as the non significant $p$ value one can say that existing practices of Six Sigma do not contribute to the improving peoples' equity. Hence, HD0 fails to get rejected.

\section{HE0: Existing practices of Six Sigma do not improve customer satisfaction.}

To test this hypothesis as a first step, it is required to calculate the overall mean and standard deviation for the variable. The following table 8 gives the value of the mean for the above variable. As a matter of policy by the companies, since there are sixteen factors that define the variable customer satisfaction, the overall test value is $3.6 * 16=57.6$.

With this calculated mean value is observed to be more than the test value. It gives the impression that Six Sigma implementation has helped the companies to improve their customers' satisfaction. This can be substantiated with the help of one sample t-test conducted at a significance level of 0.05 at 521 degrees of freedom $(\mathrm{N}-1)$.

Table 8. Mean observed and expected values on customer satisfaction and results of one sample t-test

\begin{tabular}{|l|l|l|l|l|l|l|}
\hline & $\mathrm{N}$ & $\begin{array}{l}\text { Observed } \\
\text { value } \\
\text { Mean }\end{array}$ & $\begin{array}{l}\text { Std. } \\
\text { Deviation }\end{array}$ & $\begin{array}{l}\text { Expected } \\
\text { value of } \\
\text { Mean }\end{array}$ & t-value & $\mathrm{p}$-value \\
\hline $\begin{array}{l}\text { Customer } \\
\text { satisfaction }\end{array}$ & 522 & 61.084 & 7.594 & 57.6 & 5.064 & $\begin{array}{l}0.000 \\
\text { (highly } \\
\text { significant) }\end{array}$ \\
\hline
\end{tabular}

The positive value of $t$ signifies that obtained mean is greater than the test value. Further the significance value $\mathrm{p}(0.000)<\mathrm{p}(0.05)$, this indicates that as the obtained mean value is greater than the test value, the implementation of Six Sigma towards the improvement of their customers' satisfaction is significant, $\mathrm{t}(521)=5.064, \mathrm{p}<0.05$. Hence, we can say that the implementation of Six Sigma has significantly contributed to the improvement of customers' satisfaction as per the opinions of the respondents. Thus hypothesis HE0 is rejected.

\section{HF0: There is no relationship among the benefits of Six Sigma}

Till now we have observed that practices of Six Sigma is not uniform with every company. This could be due to various factors like culture, type of the product, management perception, interrelationship among benefits, etc. The interrelationship among the benefits will reveal the effect of one variable on the other. Thus if the set practice of Six Sigma in one company affects one variable, it would affect all the variables, if those variables are interrelated with each other. We will obtain a correlation matrix for the above test.

The following table 9 gives the details of the relationship among various benefits contained in practice of Six Sigma at a significance level of 0.01 (two tailed) 
Table 9. Correlations among the benefits of Six Sigma

\begin{tabular}{|c|c|c|c|c|c|c|}
\hline & & $\begin{array}{c}\text { Customer } \\
\text { satisfaction }\end{array}$ & $\begin{array}{c}\text { Financial } \\
\text { benefits }\end{array}$ & $\begin{array}{l}\text { Growth of } \\
\text { the } \\
\text { company }\end{array}$ & $\begin{array}{l}\text { Peoples' } \\
\text { equity }\end{array}$ & Productivity \\
\hline \multirow{2}{*}{$\begin{array}{l}\text { Customer } \\
\text { satisfaction }\end{array}$} & r value & 1 & $.722(* *)$ & $.645(* *)$ & $.612(* *)$ & $.607(* *)$ \\
\hline & $\mathrm{p}$ value & . & .000 & .000 & .000 & .000 \\
\hline \multirow{2}{*}{$\begin{array}{l}\text { Financial } \\
\text { benefits }\end{array}$} & r value & & 1 & $.851(* *)$ & $.742(* *)$ & $.682(* *)$ \\
\hline & $\mathrm{p}$ value & & . & .000 & .000 & .000 \\
\hline \multirow{2}{*}{$\begin{array}{l}\text { Growth of the } \\
\text { company }\end{array}$} & r value & & & 1 & $.727(* *)$ & $.794(* *)$ \\
\hline & $\mathrm{p}$ value & & & . & .000 & .000 \\
\hline \multirow{2}{*}{$\begin{array}{l}\text { Peoples' } \\
\text { equity }\end{array}$} & r value & & & & 1 & $.698(* *)$ \\
\hline & $\mathrm{p}$ value & & & & & .000 \\
\hline \multirow[t]{2}{*}{ Productivity } & r value & & & & & 1 \\
\hline & $\mathrm{p}$ value & & & & & . \\
\hline
\end{tabular}

The Pearson correlation coefficient (r) values indicate the size of the correlation. Squaring the $r$ value indicates the percentage of affect of one variable over the other.

The following observations can be made with the help of the table 9

a. The customer satisfaction has a significant positive relationship with financial benefits, growth of the company, peoples' equity, and productivity. Its highest significance is seen with financial benefits $(52.2 \%)$, which means that increase in customer satisfaction will help the company to improve its financial position by $52 \%$.

b. Financial benefits are having significant positive relationship with customer satisfaction, growth of the company, peoples' equity, and productivity. Its highest significance is seen with growth of the company $(72.4 \%)$, which means the increase in the financial position of the company will affect the growth of the company to an extent of $72 \%$.

c. Growth of the company is having significant positive relationship with customer satisfaction, Financial benefits, peoples' equity, and productivity. Its highest significance is seen with financial benefits $(72.4 \%)$, which means the growth of the company will be affected to an extent of $72 \%$ with the improvement in the financial position of the company.

d. Peoples' equity in a company is having significant positive relationship with 
customer satisfaction, financial benefits, growth of the company, and productivity. Its highest significance is seen with financial benefits $(55 \%)$, which means that the peoples' equity of the company will increase to an extent of $55 \%$ with the improvement in the financial position of the company.

e. Productivity of the company is having significant positive relationship with customer satisfaction, financial benefits, growth of the company, and peoples' equity. Its highest significance is seen with financial benefits $(63 \%)$, which mean that the improved productivity of the company will help the company to grow to an extent of $63 \%$.

Since the correlation matrix revealed a significant interrelationship among all the benefits of Six Sigma, hypothesis HFO is rejected

\section{Discussions and conclusions}

The Six Sigma is being recognized as critical for the success of any industry. Six Sigma has complemented TQM in achieving continuous improvement by providing new structure and methods.

It is very important for managers to be aware of the cultural values before adopting TQM/Six Sigma initiatives, in their organization that can help to effectively implement multiple TQM/Six Sigma practices in the organization.

A detailed study of the manufacturing industries that have implemented Six Sigma in India, followed by analysis of the results reiterated vital role of Six Sigma in making manufacturing industries achieve success. The study was aimed at understanding the employees' impression about the impact of implementation of Six Sigma on few success variables such as growth of the company, financial benefits, productivity, peoples' equity and customer satisfaction; examine the interrelationship among the benefits of Six Sigma. The following conclusions are highlighted after the study.

I. Collective responses indicate that the implementation of Six Sigma has done huge impact on the growth of the company. This means that respondents have consented positively towards the fact that due to Six Sigma the brand image of the company has improved and company has obtained a competitive edge due to Six Sigma.

II. Respondents have the opinion that Six Sigma implementation has a positive impact on the improvement of the financial position of the company, as they feel that parameters like reduced cost of poor quality, reduced price of non conformance, improved profit and return on investment have contributed to the improved financial position of the organization.

III. Analysis of the impact of Six Sigma on productivity also indicate a positive relationship as respondents have given thumbs up for improved productivity. They have reacted that factors like setup cost, operating cost, scrap rate, defect rate, rejection rate, production lead time have come down after Six Sigma is implemented, which has resulted in improved process capability. This impact has resulted in improved productivity after Six Sigma implementation.

IV. The variable, peoples' equity that highlighted parameters towards the welfare of the work force do not appears to be in a better shape even after the implementation of Six Sigma. Respondents have observed that factors like human values, morale of the employees, working culture have improved due to which the commitment from the workers side towards the implementation of Six Sigma is positive. But many other factors like top management commitment, leadership style, employee involvement 
in decision making, continuous need based training, interpersonal relationships, communication skills, incentive schemes, knowledge sharing between employees, employee retention, have not improved substantially. These factors have contributed to the displeasure among employees with Six Sigma. However it is observed and appreciated that they have enjoyed the implementation of Six Sigma and would like to continue in companies that have implemented Six Sigma. This indicates that by giving more attention to the monetary benefits of the workforce the impact of Six Sigma could be enhanced.

V. Finally, the most important variable in the present scenario, the customer satisfaction, is observed to have increased after implementing Six Sigma as per the opinion of the respondents. They have observed that after customers are made part of the product development, they are able to define their requirements properly. Due to reduced defects and rejection rates customers are very happy. Since, the changes suggested by the customers are made quickly, industries are able to achieve win-win situation with the customers. As a result the customer satisfaction level has improved after the implementation of Six Sigma.

VI. There is a significant interrelationship among the benefits of Six Sigma. This is a very important fact that makes the companies to understand that all benefits should be given equal importance as decrease of one will start a cascading effect on all other benefits.

\section{Implications for the management and non Six Sigma companies}

The survey results bring up the measured opinion of employees who are involved in the implementation of Six Sigma which is very unique. They believe that Six Sigma is a fruitful exercise that helps the manufacturing organizations to achieve success in various facets that includes the growth, financial benefits, satisfaction of customers, and productivity. However, the relationship between peoples' equity and Six Sigma implementation, it is not highly significant. It indicates the employees are not highly benefitted by Six Sigma implementation. This opens up the huge responsibility for the managers to consider this factor seriously. Human resource is the back bone of any organization. Hence, more thoughtfulness is expected to be extended towards the improvement of work force. This will improve the morale of the work force and they will involve to a greater degree in the change process. This starts a chain reaction and results in improving the results of other variables also to a greater extent resulting in greater success of manufacturing industries. Thus the management should look into each of the factor of peoples' equity to obtain a better result.

Finally, the results of the survey acts as a route map for non Six Sigma industries. As the employees of these manufacturing industries observe that Six Sigma implementation yields lot of benefits, not just on paper but also in the minds of employees who have worked on six sigma projects. Hence, the management of non Six Sigma industries should think proactively before the crisis occurs in their respective organization. This survey acts as a motivator for management of non Six Sigma industries to promote Six Sigma in their organization.

\section{Future scope of the study}

The study which included the benefits of Six Sigma alone cannot be compared with the success due to other manufacturing philosophies such as lean or theory of constraints 
unless we make a comparative study between such organizations. The organizations where the survey is done follow only Six Sigma methodology. This opens up future scope of the study to compare between Six Sigma and lean or other manufacturing philosophies.

\section{References}

1. M. Arendt, "Six Sigma and knowledge management", Economics and Organization of Enterprise, Vol 2, No. 2, pp14-20, 2008.

2. T Yang, C Hsieh, "Six-Sigma project selection using national quality award criteria and Delphi fuzzy multiple criteria decision-making method", Expert Systems with Applications, Vol 36, pp 7594-7603, 2009.

3. CT Su, C.J. Chou, "A systematic methodology for the creation of Six Sigma projects: a case study of semiconductor foundry", Expert Systems with Applications, Vol 34, pp 2693-2703, 2008

4. K Linderman, R.G Schroeder, S Zaheer, A.S Choo, "Six Sigma: a goal-theoretic perspective", Journal of Operations Management, Vol 21, pp 193-203, 2003.

5. J. Markarian, "Six Sigma: quality processing through statistical analysis", Plastics. Additives and Compounds, Vol 6, No.4, pp 28-31, 2004.

6. K.C Kapur, Q Feng, "Integrated optimization models and strategies for the improvement of the Six Sigma process", International Journal of Six Sigma and Competitive Advantage, Vol 1, No.2, pp 210-228, 2005.

7. Q Feng, C.M Manuel, "Under the knife: a national survey of Six Sigma programme in US healthcare organizations", International Journal of Health Care Quality Assurance, Vol 21, No.6, PP535-547, 2008.

8. R.K Padhy, S.Sahu, and R.K. Das, "Implementation of Six Sigma in Indian industries a Delphi study", Int. J. Computer Aided Engineering and Technology, Vol 3, No.1, pp 19-33, 2011.

9. C. S Chethan Kumar, N V R Naidu, K Ravindranath, "Performance improvement of manufacturing industry by reducing the Defectives using Six Sigma Methodologies" IOSR Journal of Engineering, Vol. 1, No.1, pp 001-009, 2010.

10. D. A Desai, M. B Patel, "Impact of Six Sigma in a developing economy: analysis on benefits drawn by Indian industries", Journal of Industrial Engineering and Management, Vol. 2, No. 3, pp 517-538, 2009.

11. P. Kaushik and D. Khanduja. (2009). Application of Six Sigma DMAIC methodology in thermal power plants: A case study. Total Quality Management, 20(2), 197-207.

12. P Kaushik, "Relevance of Six Sigma line of attack in SME's - a case study of die casting manufacturing unit", Journal of Engineering and Technology, Vol. , No.2, pp 107-112, 2011.

13. Min Zhang, Wei Wang, Thong Ngee Goh, and Zhen He, "Comprehensive Six Sigma application: a case study", Production Planning \& Control, Vol.26, No. 3, 2015

14. K Srinivasan, S Muthu, S R Devadasan, and C Sugumaran, "Enhancement of sigma level in the manufacturing of furnace nozzle through DMAIC approach of Six Sigma: a case study”, Production Planning \& Control, Vol.27, No.10. pp 810 - 822, 2016.

15. A. J. Thomas, M Francis, R Fisher, and P Byard, "Implementing Lean Six Sigma to overcome the production challenges in an aerospace company", Production Planning \& Control, Vol 27, No.7-8, 2016. 
16. N Venkatesh, and C Sumangala, "Evaluation of Six Sigma in Automobile Manufacturing Industries", Journal of Contemporary Research in Management, Vol.9, No.1, pp 45-54, 2014.

17. J. Nunnaly, "Psychometric theory", New York: McGraw-Hill publishers, 1978 